\title{
INL Site Conditions and Properties
}

G. Griffith
S. Hoiland

September 2015
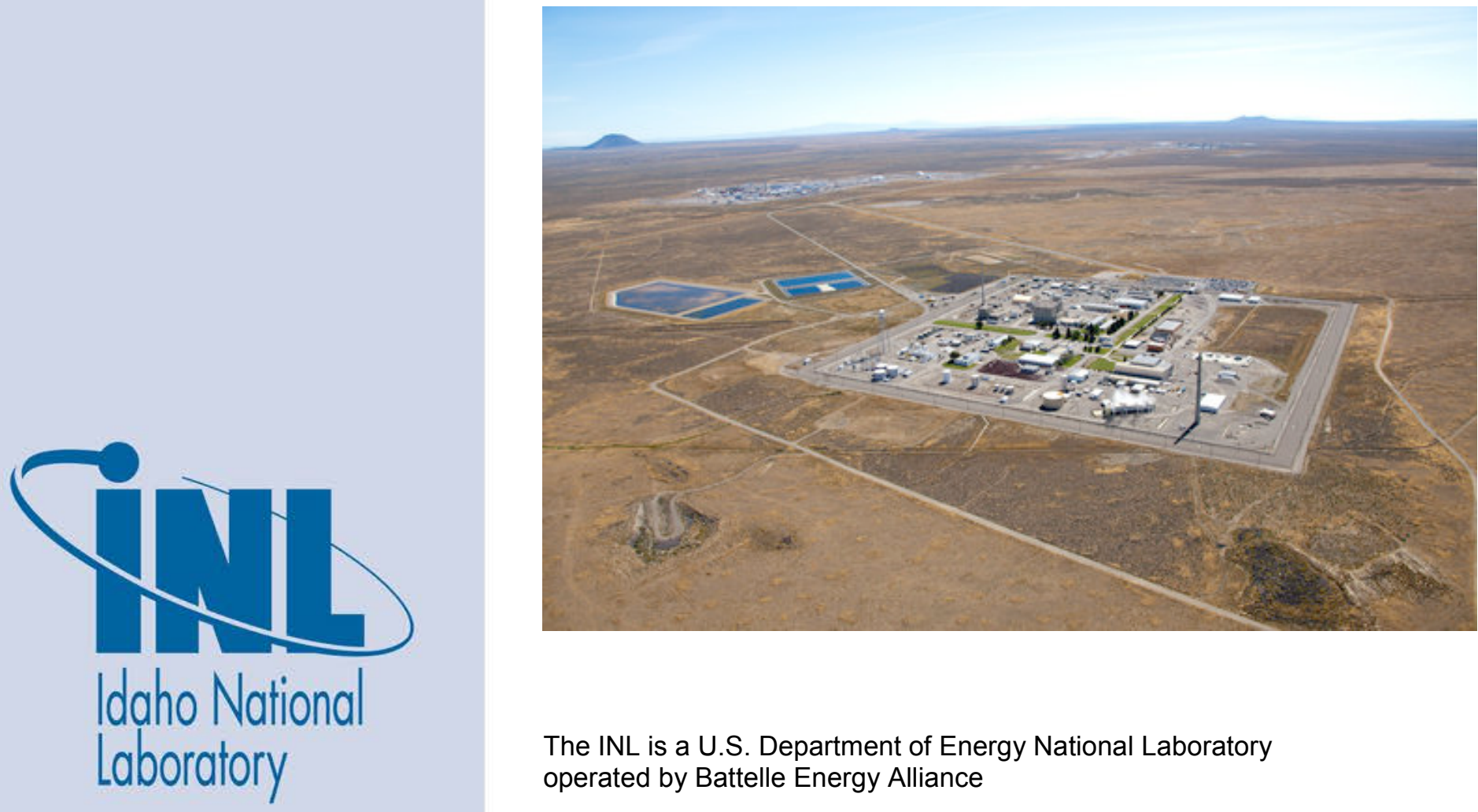

The INL is a U.S. Department of Energy National Laboratory operated by Battelle Energy Alliance 


\section{DISCLAIMER}

This information was prepared as an account of work sponsored by an agency of the U.S. Government. Neither the U.S. Government nor any agency thereof, nor any of their employees, makes any warranty, expressed or implied, or assumes any legal liability or responsibility for the accuracy, completeness, or usefulness, of any information, apparatus, product, or process disclosed, or represents that its use would not infringe privately owned rights. References herein to any specific commercial product, process, or service by trade name, trade mark, manufacturer, or otherwise, does not necessarily constitute or imply its endorsement, recommendation, or favoring by the U.S. Government or any agency thereof. The views and opinions of authors expressed herein do not necessarily state or reflect those of the U.S. Government or any agency thereof. 
INL/EXT-15-36721

Revision 0

\title{
INL Site Conditions and Properties
}

\author{
G. Griffith \\ S. Hoiland
}

September 2015

Idaho National Laboratory Idaho Falls, Idaho 83415

http://www.inl.gov

\author{
Prepared for the \\ U.S. Department of Energy \\ Office of Nuclear Energy \\ Under DOE Idaho Operations Office \\ Contract DE-AC07-05ID14517
}





\section{ABSTRACT}

This report provides a high-level review of potential technical, commercial, and natural components likely to influence the planning, preparing, and

positioning for the future by investing in the build-out of energy systems at Idaho National Laboratory. 


\section{CONTENTS}

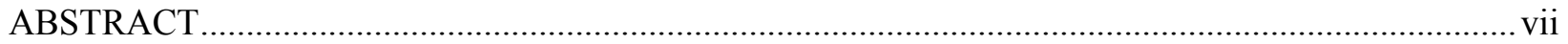

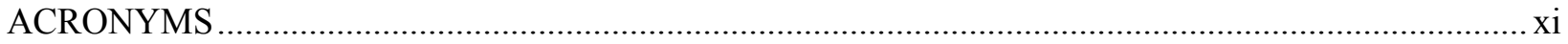

1. IDAHO NATIONAL LABORATORY IS A MULTI-PROGRAM LABORATORY ..................... 1

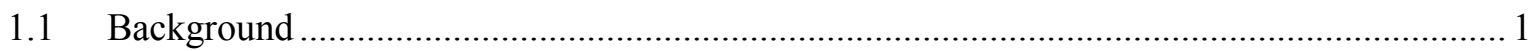

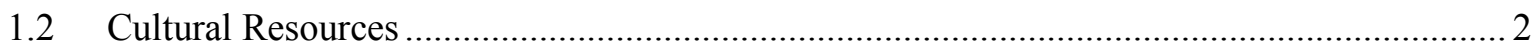

1.2.1 Prehistoric and Historic Archaeological Sites and Artifacts................................... 2

1.2.2 National Historic Landmark Buildings ................................................................ 2

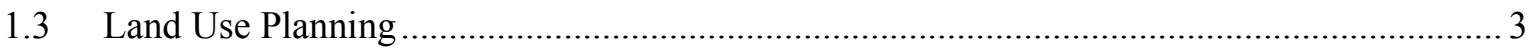

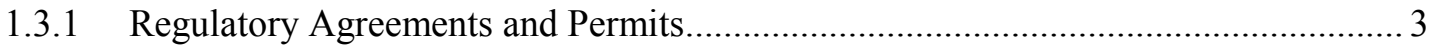

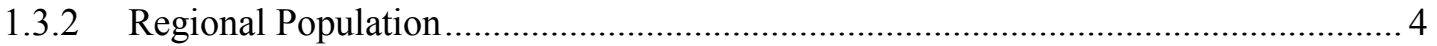

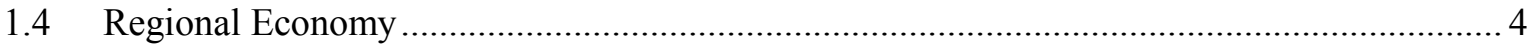

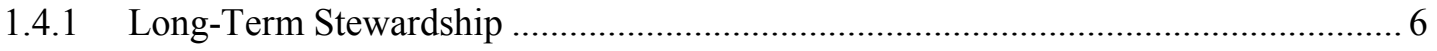

1.4.2 Non-Comprehensive Environmental Response, Compensation, and Liability Act Environmental Management Operations .......................................................... 6

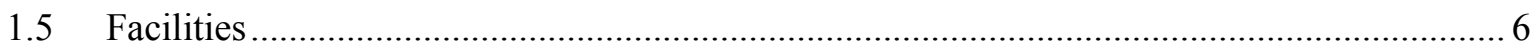

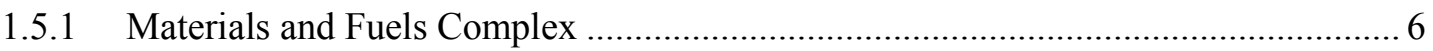

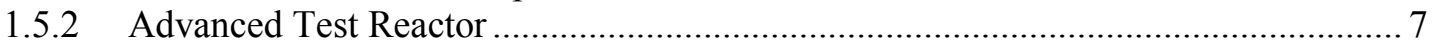

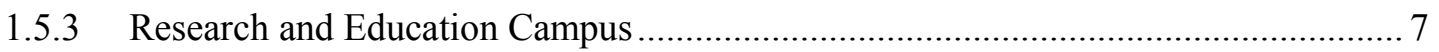

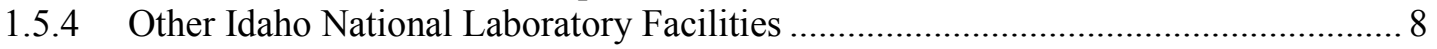

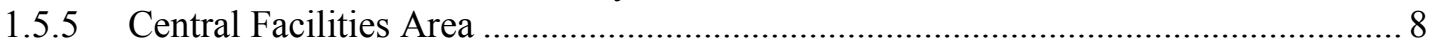

1.5.6 Idaho Nuclear Technology and Engineering Center ............................................... 8

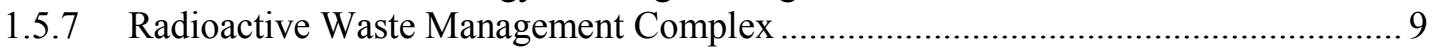

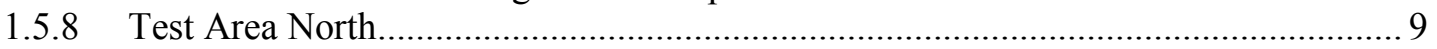

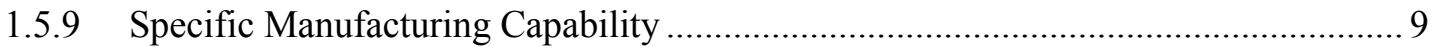

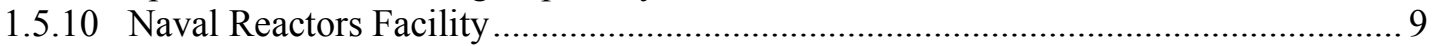

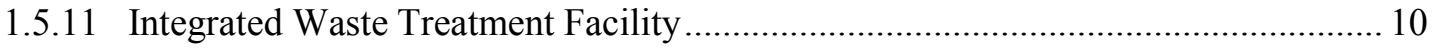

1.5 .12 Geology

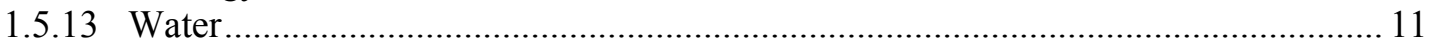

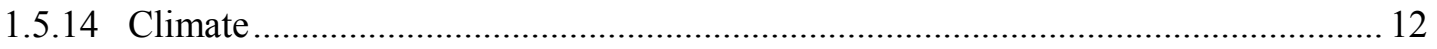

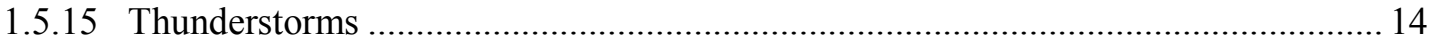

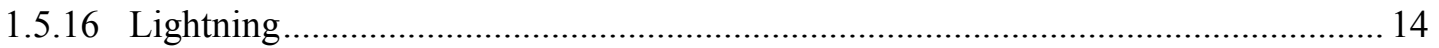

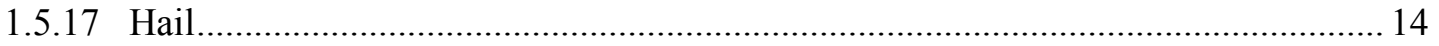

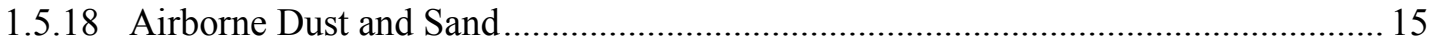

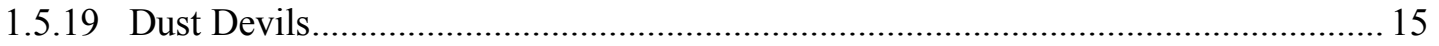

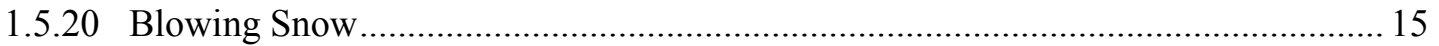

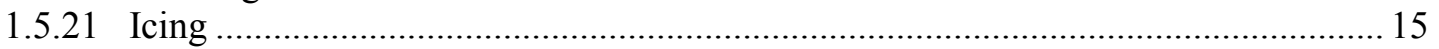

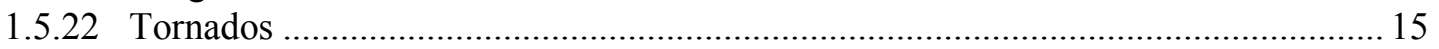

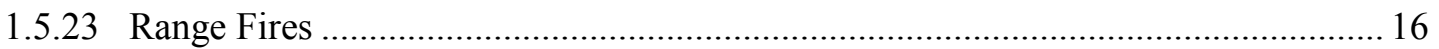




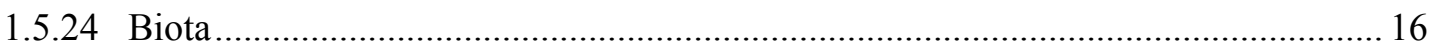

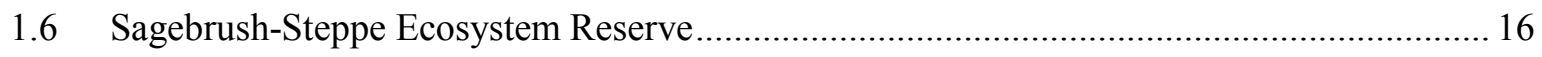

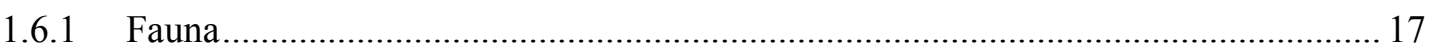

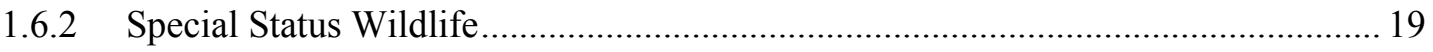

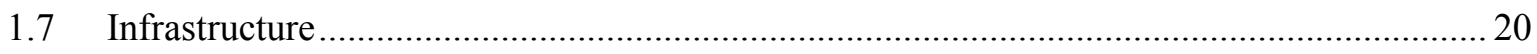

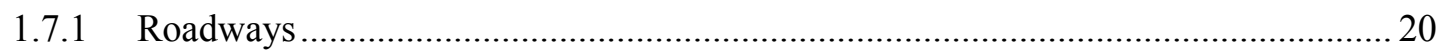

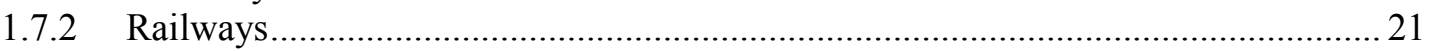

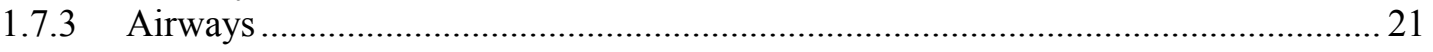

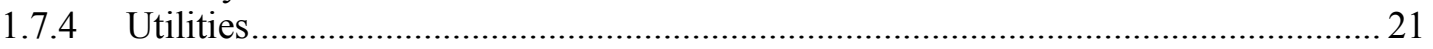

1.7.5 Seismology ...............................................................ror! Bookmark not defined.

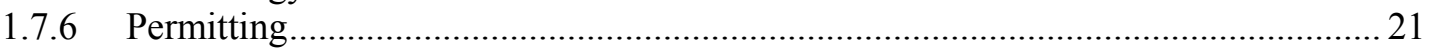

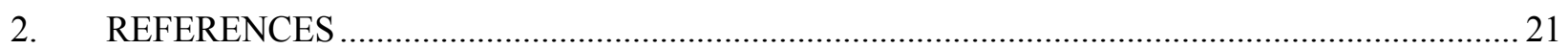

\section{FIGURES}

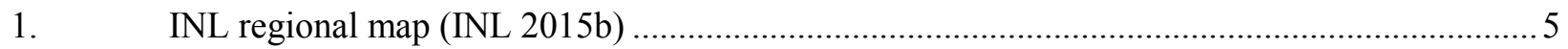

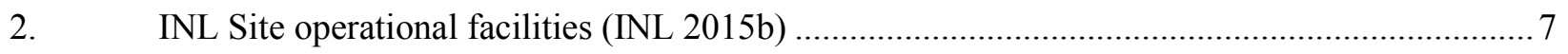

3. Eastern Snake River Plain Aquifer (Gellar 2006)........................................................... 12

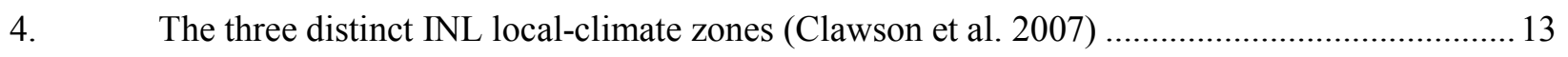

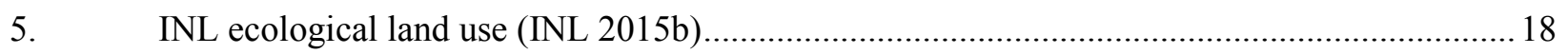

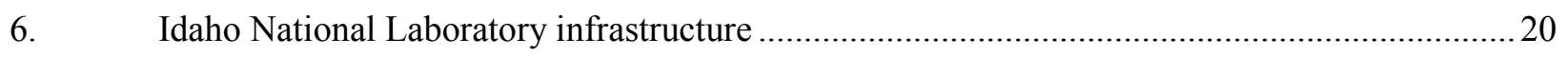

\section{TABLES}

1. Daily air temperature extremes summarized by month for CFA.......................................... 13

2. Average total monthly and annual precipitation (water equivalent) for CFA ......................... 14

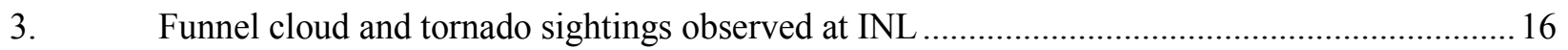




\section{ACRONYMS}

CERCLA Comprehensive Environmental Response, Compensation, and Liability Act

CFA Central Facilities Area

CITRC Critical Infrastructure Test Range Complex

DOE U.S. Department of Energy

DOE-ID U.S. Department of Energy, Idaho Operations Office

INL Idaho National Laboratory

INTEC Idaho Nuclear Technology and Engineering Center

MFC Materials and Fuels Complex

NRF Naval Reactors Facility

RWMC Radioactive Waste Management Complex

TAN Test Area North 


\section{INL Site Conditions and Properties \\ 1. IDAHO NATIONAL LABORATORY IS A MULTI-PROGRAM LABORATORY}

Idaho National Laboratory (INL) is a science-based, applied engineering national laboratory dedicated to meeting the nation's environmental energy, nuclear technology, and national security needs.

The U.S. Department of Energy (DOE) Idaho Operations Office (DOE-ID) oversees these contract activities in accordance with DOE directives.

In addition to enabling the DOE Office of Nuclear Energy to develop space power systems and advanced fuel cycle and reactor technologies, INL facilities are used by the National Nuclear Security Administration and other DOE offices, together with other federal agencies such as the Department of Defense and Department of Homeland Security, to meet an array of strategic energy, environmental, and national security goals (Energy.gov 2015).

\subsection{Background}

INL, an 890-square-mile section of desert in southeast Idaho, was established in 1949 as the National Reactor Testing Station. Initially, the missions at INL included development of civilian and defense nuclear reactor technologies and management of spent nuclear fuel. Fifty-two reactors - most of them first-of-a-kind - were built, including the Navy's first prototype nuclear propulsion plant. Of the 52 reactors, three remain in operation at the INL Site, with a fourth scheduled to be restarted in the near future.

In 1951, INL achieved one of the most significant scientific accomplishments of the century-the first use of nuclear fission to produce a usable quantity of electricity at Experimental Breeder Reactor-1-. The Experimental Breeder Reactor-1-is now a Registered National Historic Landmark that is open to the public.

During the 1970s, the name of the INL Site was changed from the National Reactor Testing Station to the Idaho National Engineering Laboratory to reflect its broadened mission into areas like biotechnology, energy and materials research, and conservation and renewable energy. The INL Site's name changed again in the spring of 1997 to the Idaho National Engineering and Environmental Laboratory to reflect a major refocus of the laboratory, present and long-term, toward engineering applications and environmental solutions, as well as the Comprehensive Environmental Response, Compensation, and Liability Act (CERCLA) environmental cleanup of INL under the DOE office of Environmental Management and the Federal Facility Agreement and Consent Order. Beginning on February 1, 2005, the name changed again to Idaho National Laboratory. This change reflects a move back to the laboratory's historic roots in nuclear energy and national security.

Under the purview of DOE-ID, INL is home to the largest concentration of technical professionals in the Rocky Mountain region. Sponsorship of INL was formally transferred to the DOE Office of Nuclear Energy, Science, and Technology (DOE-NE) by Secretary Spencer Abraham in July 2002. The move to DOE-NE supports the nation's expanding nuclear energy initiatives, placing INL at the center of work to develop advanced Generation IV nuclear energy systems; nuclear energy/hydrogen co-production technology; and advanced nuclear energy fuel cycle technologies, as well as provide national security answers to national infrastructure needs.

Today, INL and DOE-ID support many DOE program offices and federal agencies. In addition, the INL Site hosts the National Nuclear Security Agency's Naval Reactors Facility (NRF). The INL Site also maintains an active presence by the National Oceanic and Atmospheric Administration and the United States Geological Survey. 
In addition, the INL Site is a National Environmental Research Park, one of only seven in the nation. It is situated on otherwise unoccupied, undeveloped, semi and high-desert terrain surrounded by prominent mountain ranges. All lands within the INL Site boundaries are a protected outdoor laboratory, where scientists from DOE, other federal and state agencies, universities, and private research foundations conduct ecological studies(DOE-ID 2010).

\subsection{Cultural Resources}

The INL Site is home to a rich cultural heritage spanning at least 13,500 years of human occupation in southeastern Idaho. Several types of cultural resources exist across the landscape, including prehistoric and historic archaeological sites and artifacts; sites and artifacts of importance to the Shoshone-Bannock Tribes and others, such as the California and Oregon Trail Association; and historic architectural properties from the World War II timeframe. Resources representing America's pioneering nuclear era, including structures, buildings, objects, artifacts, and documents, also are present. Natural landforms and native plants and animals of the INL region also may be of traditional importance to Native Americans, and, although rare, human burials have been found on the INL Site and are of special importance. DOE allows access to certain areas of the INL Site to Shoshone-Bannock tribal members for activities related to the maintenance of tribal heritage, education of tribal members, and exercise of traditional cultural activities.

The thousands of historic and prehistoric archaeological sites within the INL Site boundaries range in age from more than 70 to 13,500-yearsold. Evidence of homesteads, stage stations, irrigation attempts, and trails also are extant. The INL Cultural Resource Management archives include documentation of nearly 3,000 archaeological resources and nearly 300 historic buildings and other structures. The newly established INL Archive Center houses artifacts such as engineering and architectural drawings, 16-mm films, and photographic negatives(INL 2015b).DOE--ID is tasked, by law, with managing this important cultural heritage in accordance with federal and state requirements and internal orders and directives.INL is committed to protecting and preserving cultural resources across the site.

Strategies for effective management of INL Site cultural resources have been developed in conjunction with pertinent INL programs and are detailed in DOE-ID's Cultural Resource Management Plan(INL 2015b).A tailored approach to management of these resources and compliance with applicable federal and state laws are included in the INL Cultural Resource Management Plan, which is the basis of the programmatic agreement among DOE-ID, the Idaho State Historic Preservation Office, and the Advisory Council on Historic Preservation, as well as an Agreement-in-Principle between DOE-ID and the Shoshone-Bannock Tribes.

\subsubsection{Prehistoric and Historic Archaeological Sites and Artifacts}

Efforts to inventory INL Site cultural resources are ongoing. These investigations have been completed in project-specific locations and areas identified within research designs. To-date, approximately $10 \%$ of the $2,303-\mathrm{km}^{2}\left(889-\mathrm{mi}^{2}\right)$ INL Site has been inventoried for archaeological sites, resulting in an inventory of nearly 3,000 resources. Archive and collections management for INL Site cultural resources is conducted on a variety of levels. Legal guidelines are followed to ensure preservation of these important materials in perpetuity for the benefit of the American people.

\subsubsection{National Historic Landmark Buildings}

Over 500 INL Site buildings have been surveyed and been assessed for their eligibility to the National Register of Historic Places and over nearly 300 were identified as historic and potentially eligible for nomination. Inventories of historic architectural properties at NRF have not been completed and efforts to inventory significant INL Site objects are ongoing. At present, the only INL Site properties formally listed as National Historic Landmarks are the EBR-I reactor and guardhouse. The EBR-I National 
Historic Landmark is open to the public daily from Memorial Day through Labor Day each year. It offers educational displays and guided tours on INL's historic nuclear past and on nuclear power in general.

Aviators Cave, an important Native American resource and sensitive archaeological site, also has been listed. Many other archaeological resources on the INL Site are potentially eligible for nomination.

Fifteen other INL Site architectural properties have been designated as signature properties. Signature property is a term coined by DOE that denotes it's most historically important properties across the complex or those properties that are viewed as having tourism potential(INL 2015b).

\subsection{Land Use Planning}

Land use planning is the overarching function within real property asset management that integrates the other functions of acquisition, recapitalization, maintenance, disposition, real property utilization, and long-term stewardship into a coordinated effort to ensure current and future mission needs are met. To achieve their full potential, DOE sites are given, under the life-cycle asset management approach, the responsibility of tailoring the process to local conditions and to existing activities that impact planning for DOE's land and facility assets(INL 2015b).

The INL Site has tailored its land use planning process based on DOE Order 430.1B, "Real Property Asset Management." Briefly, all projects planned at the INL Site are considered through a formal planning process. The planning process includes land use committees from both DOE-NE (through Battelle Energy Alliance) and DOE-ID. Requests are submitted to DOE-NE (via the Campus Development Office), which uses a standard consideration process to look at mission goals, existing and past uses, resources of concern, and many other factors in relation to the requested project. Both DOE and the contractor have a land use committee. These committees, composed of individuals representing the interests of DOE-NE and DOE Office of Environmental Management, review proposals that may have an impact on the INL Site's lands and issue recommendations to senior leadership, who make the final decision on the proposed project(INL 2015b).

A number of environmental factors/resources at INL need to be considered during planning because of the potential for impacts to these resources from actions that may result from planning. The types of factors that are considered include regional considerations such as population, land uses, and socioeconomic conditions; site wide area infrastructure such as transportation routes, power distribution systems, communication systems, utility systems, and other land uses; resources such as soils, water resources, biota, and cultural resources; and natural hazards at the INL Site such as wildland fire, seismic hazards, and floods.

All proposed projects are subject to the National Environmental Policy Act and its public involvement processes. In addition, land use plans will be available to the public, including federal, tribal, state, and local stakeholders sharing an interest in INL Site land use. Land use planning will remain a current and living process by using adaptive management techniques that adjust management practices and direction to changes in environmental, mission, economic, cultural, and social factors.

\subsubsection{Regulatory Agreements and Permits}

Current INL Site operations include environmental remediation and ongoing research, testing, and development activities that are conducted pursuant to regulatory agreements and permits. CERCLA, commonly known as Superfund, was enacted by Congress on December 11,1980, and governs environmental remediation, including remediation of federal facilities such as the INL Site.

The INL Site was placed on the National Priorities List in November1989. This required DOE to enter into a Federal Facility Agreement and Consent Order with the Environmental Protection Agency and the State of Idaho for effective management of the INL Site. The INL Site Federal Facility Agreement and Consent Order was signed December 9,1991. Among other things, the purpose of the Federal Facility Agreement and Consent Order is to ensure that the environmental impacts associated 
with historical releases of hazardous and radioactive contaminants into the air, groundwater, and soils of the INL Site from projects supporting Cold War activities over the last 50 years are thoroughly investigated and that appropriate response actions are undertaken and completed, as necessary, to protect public health and welfare and the environment.

\subsubsection{Regional Population}

Sixteen counties are within $80 \mathrm{~km}(50 \mathrm{mi})$ of the INL Site. Fifteen of these counties are in the State of Idaho and one is in the State of Montana. This 16-county region has a low population density. In 2010, the population for this region was 390,608 (Census Bureau 2011). Nearly $48 \%$ of this population resides in the two most populous counties: Bonneville and Bannock.

The largest regional cities are Idaho Falls (located in Bonneville County), with a2010 estimated population of 56,891 residents, and Pocatello (located in Bannock County), with a2010 estimated population of 54,224 residents. These two cities represent approximately $28 \%$ of the regional population. The Fort Hall Indian Reservation is located south of the INL Site. It has a 2010 estimated population of 3,201. A regional perspective of the INL Site and surrounding population centers is shown in Figure 1.

The entire INL Site is an administratively controlled area. In general, admittance to the INL Site and its facilities is permitted only on an "official business" basis. The Shoshone-Bannock Tribes have been granted access to an area around and including the Middle Butte Cave; public access is allowed in rights-of-way associated with highways, the Big Lost River rest area, and at the EBR-I visitor center. There are no human residences on INL Site property.

The region adjacent to the INL Site boundary is a combination of public and private land. Approximately $75 \%$ of the land adjacent to the INL Site is managed by the federal government and administered by the U.S. Bureau of Land Management. This federally managed land provides wildlife habitat and is used for mineral and energy production, grazing, and recreation. Approximately $1 \%$ of the adjacent land is owned by the State of Idaho and is used for the same purposes as the federal land. The remaining $24 \%$ of the land adjacent to the INL Site is privately owned and primarily is used for grazing and crop production.

In 2007, approximately 993,195 acres of cropland were in use each year within the five-county area that encompasses the INL Site(INL2015b. Population densities are generally low, with urban and suburban land uses spatially distant. The Big Southern Butte is south of the INL border and the Middle and Eastern Buttes are within the INL Site near the south border. Significant portions of these primarily federal-owned lands are used for recreational purposes, such as hunting, fishing, boating, hiking, crosscountry skiing, and camping. Specific recreational and tourism sites are located near the INL Site at the Craters of the Moon National Monument, Hell's Half-Acre Wilderness Study Area, Black Canyon Wilderness Study Area, Camas National Wildlife Refuge, Market Lake State Wildlife Management Area, Mud Lake Wildlife Management Area, and the Birch Creek Camping Area. The Big Southern Butte and Hell's Half Acre are designated as National Natural Landmarks. EBR-I is a National Historic Landmark. In addition, there are two national forests, Challis-Salmon and Targhee-Caribou, within 50 miles $(80 \mathrm{~km})$ of the north and west INL Site boundaries, respectively(INL 2015b.

\subsection{Regional Economy}

In2010, an analysis of INL's impacts on the economy of Idaho was conducted (BSU 2010). The analysis showed that the annual impacts of INL operations on employment, output, and income in Idaho are large by any measure. They are especially significant in Idaho's largely rural economy and crucial to the economy of eastern Idaho. INL's 8,016 employees made the laboratory the second-largest employer in Idaho in 2009 , ranking only behind the state government. In total, the combined direct, indirect, and induced effects of INL's activities are estimated to be responsible for 24,149 jobs in the state on an annual basis. With approximately 683,000 jobs in Idaho, INL annually accounts for over $3.5 \%$ of all jobs in the 
state. The effect on employment is even greater in eastern Idaho, where INL is responsible for over $15 \%$ of all jobs in the region.
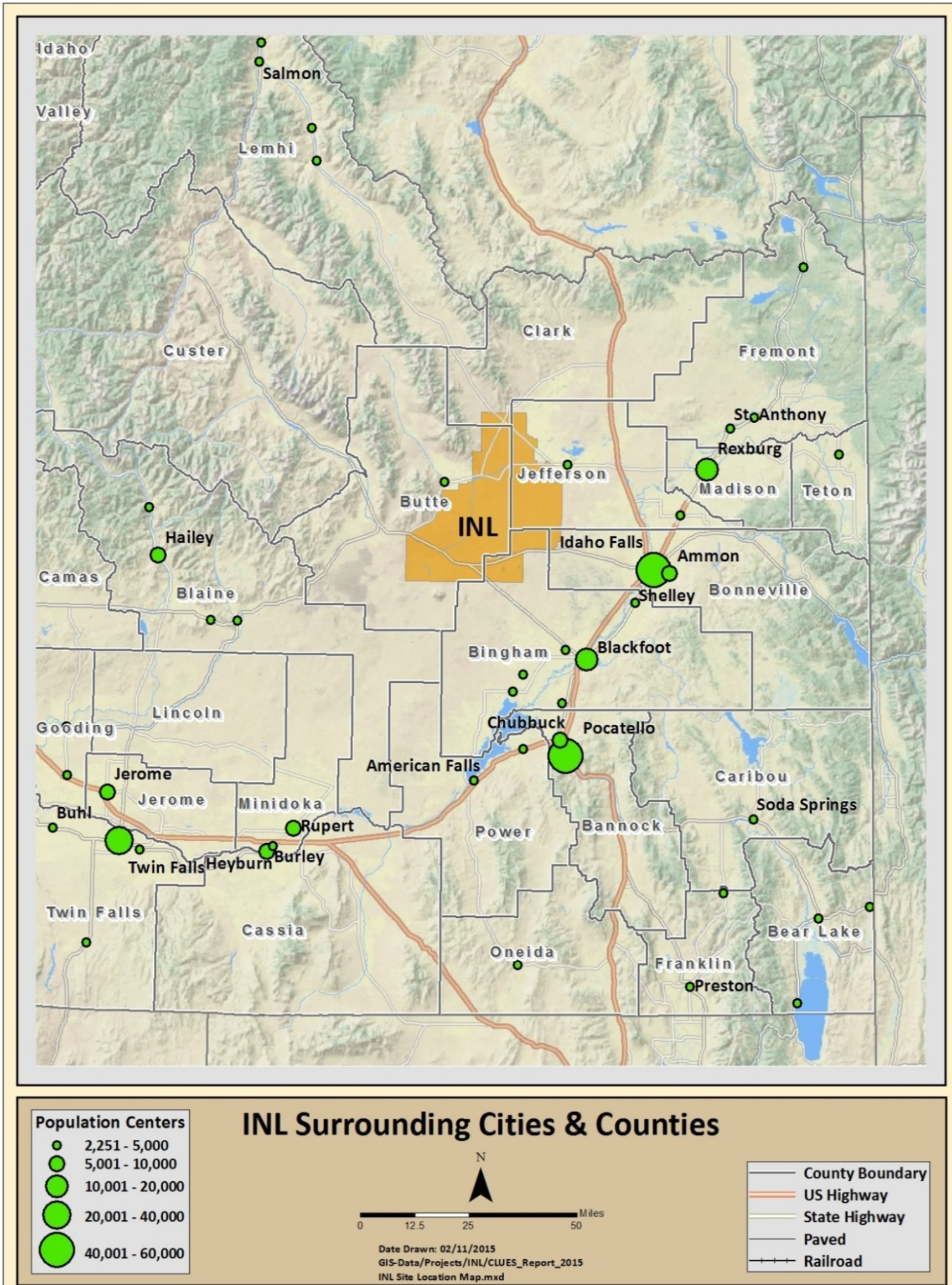

Figure 1. INL regional map (INL 2015b). 
In addition to INL's impact on employment, the direct, indirect, and induced effects of its operations contribute nearly $\$ 2.9$ billion to Idaho's production, amounting to about $6 \%$ of the state's total output. Additionally, INL contributes $\$ 1.83$ billion to personal income in the state, amounting to $3.5 \%$ of all personal income in Idaho.

The presence of INL and its workforce has changed the employment composition of eastern Idaho and the state as a whole, making Idaho more economically diverse. Without INL, the eastern part of the state would be more reliant on agricultural production, agricultural inputs, and transportation services. Economic fluctuations in any given sector have less impact on other parts of the economy due to the presence of a more diverse economy(INL 2015b).

\subsubsection{Long-Term Stewardship}

Long-term stewardship refers to all activities that are necessary to ensure protection of human health and the environment following completion of cleanup, disposal, or stabilization of a site or a portion of a site. Following completion of major environmental remediation efforts at the INL Site, many locations will require long-term stewardship because residual contamination will remain at levels that prohibit unrestricted access. INL expects to have responsibility for long-term stewardship of the INL Site once the DOE Office of Environmental Management cleanup mission is complete. The INL Site, as part of its overall landlord responsibility, will manage these activities.

There are two ways sites typically become subject to long-term stewardship requirements. The first is when a site has been remediated and its remedial action objectives are completed or when its remedy is operating at steady-state (for instance, a groundwater pump and treat facility). A number of sites at the INL Site have been remediated to the point that no hazards remain following completion of remedial operations. The second is when a site is newly identified as a No Further Action site not requiring remediation, but the site requires ongoing operations and maintenance or the use of institutional controls because hazards remain, thus precluding release of these sites for unrestricted use.

Long-term stewardship includes all engineered and institutional controls designed to contain or to prevent exposures to residual contamination and waste, such as surveillance activities, record-keeping activities, inspections, groundwater monitoring, ongoing pump and treat activities, cap repair, maintenance of entombed buildings or facilities, maintenance of other barriers and containment structures, access control, and posting of signs.

\subsubsection{Non-Comprehensive Environmental Response, Compensation, and Liability Act Environmental Management Operations}

Operations are conducted at the INL Site in support of the non-CERCLA environmental management commitments and milestones for management of waste and spent nuclear fuel. Operations includespent nuclear fuel operations, sodium-bearing waste treatment, calcine treatment, and advanced mixed waste treatment (INL 2015b). Site operational facilities are shown in Figure 2.

\subsection{Facilities}

Day-to-day operations are conducted at three primary facility areas at INL, with each hosting the complementary resources necessary to support national priority research. One area focuses on nuclear materials and processing, another on reactor technologies, and the third on science, technology, and education integration. To maintain and expand on its distinctive capabilities in nuclear energy research, development, demonstration, and deployment, INL has begun a broadly based infrastructure revitalization effort.

\subsubsection{Materials and Fuels Complex}

The Materials and Fuels Complex (MFC), located on the INL Site, is a prime testing center for advanced technologies associated with nuclear power systems (INL 2015a). This complex is the nexus of 
research on new reactor fuels and related materials. As such, it contributes significantly to development of increasingly efficient reactor fuels and the important work of nonproliferation. The 8,200- $\mathrm{ft}^{2}$ supports nuclear power industry and other laboratories, universities, and international organizations. MFC is located 32 miles west of Idaho Falls on the high desert sagebrush steppe of the Snake River Plain.

\section{9,135 Acres 889 Square Miles}

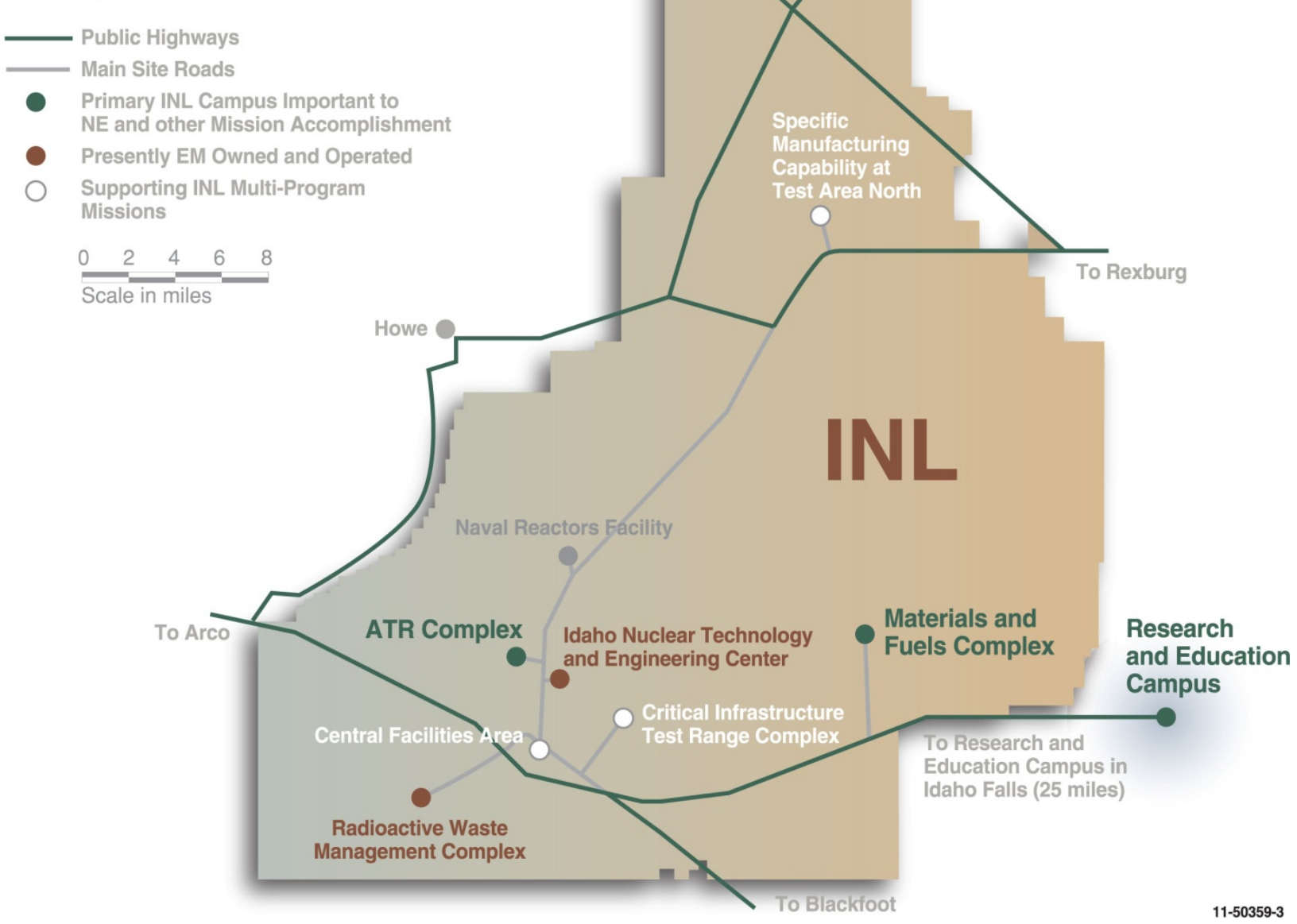

Figure 2. INL Site operational facilities (INL 2015b).

\subsubsection{Advanced Test Reactor}

Also located on the INL Site, the Advanced Test Reactor Complex is dedicated to research supporting DOE missions and is the focal point for designing, testing, and proving new technologies. The facility's work scope is broad, far-reaching, and encompasses multiple technological options important to upcoming generations of nuclear power reactors.

Recently constructed or upgraded buildings at the Advanced Test Reactor Complex include the Test Train Assembly Facility, Technical Support Building, Radio analytical Chemistry Laboratory and the Radiation Measurements Laboratory. The Advanced Test Reactor Complex is located in the southwestern region of the INL Site, 47 miles west of Idaho Falls.

\subsubsection{Research and Education Campus}

The Research and Education Campus is the collective name for INL's administrative, educational, technical support, and computer facilities in Idaho Falls, as well as in-town laboratories where researchers 
work on a wide variety of advanced scientific research and development projects. The campus name reflects the laboratory's connection to university and energy research.

\subsubsection{Other Idaho National Laboratory Facilities}

The Critical Infrastructure Test Range Complex (CITRC) offers an isolable electrical transmission and distribution system and a comprehensive communications test bed. CITRC is a national resource that supports research, development, and demonstration of technologies, systems, and policies to protect the nation's infrastructure. CITRC encompasses a collection of specialized test beds and ranges, including the full-scale Electric Power Reliability Test Bed; the carrier-grade Wireless Test Bed for integrated power and wireless testing; and the Water Test Bed, which is a full-scale representation of a municipal water system; the Radiological Dispersion Devices Training Ranges and Biotechnology Center, where specialized, hands-on training is conducted with military and civilian first responders; and locations utilized for nuclear nonproliferation detection testing and aqueous reprocessing. CITRC creates a centralized location where government agencies, utility companies, and equipment manufacturers can work together to develop or test solutions to many of the nation's most pressing security issues.

A 10-acre explosives range situated between MFC and Test Area North (TAN)can handle a variety of energetic experiments, including explosive events with a maximum charge weight of 20,000 lb TNT equivalent and shoulder-fired artillery such as rocket-propelled grenades. The purpose of the explosives test range is to study the physical impacts that modern, high-yield explosives have on buildings, barriers, and security systems (INL 2015c).

The Live Fire Test Range, which is located on 330 acres of desert terrain, consists of eight indoor and outdoor ranges and tactical training factories. One of the Physical Security Test Beds provides for testing of handguns, rifles, and heavy weapons, such as machine guns, precision rifles, grenade launchers and shoulder-fired, anti-armor weapons. The range also allows for explosive training and testing, including breaching.

The Unmanned Aerial Vehicles Program, which is one of the Physical Security Test Beds, includes hand-launched systems, rotorcraft, and larger craft, which weigh about $55 \mathrm{lb}$ and can carry a load of up to $20 \mathrm{lb}$ (INL 2015d).

\subsubsection{Central Facilities Area}

The Central Facilities Area (CFA) is located in the south-central portion of the INL Site, is about 3 miles northwest of the intersection of Highways 20 and 26, and is the main service and support center for INL's desert facilities.

CFA is an industrial support area originally developed for use by the Navy and has since served as the location for many support services for operations at the INL Site. Functions housed at CFA include laboratories, security operations, fire protection, a medical facility, communication systems, warehouses, a cafeteria, vehicle and equipment pools, and the bus system. An industrial waste landfill lies at the northern edge of CFA(DOE 2014).

\subsubsection{Idaho Nuclear Technology and Engineering Center}

Idaho Nuclear Technology and Engineering Center(INTEC), formerly the Idaho Chemical Processing Plant, is situated in the south-central portion of the INL Site. From 1952 until 1992, operations at INTEC were primarily related to the reprocessing of spent nuclear fuel from defense projects involving extraction of reusable uranium from spent fuels. After fuel dissolution and extraction, high-level liquid waste was stored in stainless steel underground tanks in the tank farm. The high-level liquid waste was calcined and the resultant granular solids (i.e., calcine) were stored in stainless steel bins encased in thick concrete

vaults. In 1992, DOE announced that the reprocessing component of the INTEC mission would be phased out, which led to the phase-out of all related processes at INTEC. The current mission for INTEC is to 
receive and temporarily store spent nuclear fuel and radioactive waste for future disposition, manage waste, and perform remedial actions(INL 20015b).

\subsubsection{Radioactive Waste Management Complex}

The Radioactive Waste Management Complex (RWMC) was established in 1952 to bury solid low-level radioactive waste from research programs. Starting in 1954 the facility also received defense waste for storage. While burial ground operations commenced in the early $1950 \mathrm{~s}$, the oldest permanent building at RWMC was constructed in 1974. The Subsurface Disposal Area, a 97-acre radioactive waste landfill on the western section of the site, was used to dispose of transuranic waste, which largely came from the Rocky Flats Plant in Colorado, and organic sludge from 1954 until 1970. In 1984, INL began a policy of only accepting low-level waste from its own activities and stopped accepting shipments from other sites. Of the 97 acres, 36 were estimated to contain waste such as radioactive elements, organic solvents, acids, nitrates, and metals(Global Security 2015a).

\subsubsection{Test Area North}

TAN is located in the northern portion of the INL Site. In general, TAN consisted of facilities originally built for handling, storing, examining, researching, and developing spent nuclear fuel. The U.S. Air Force and Atomic Energy Commission Aircraft Nuclear Propulsion Program, which supported nuclear-powered aircraft research, originally built TAN between 1954 and 1961. After that, research was terminated in 1961, the major program at TAN was the Loss-of-Fluid Test, which performed reactor safety testing and behavior studies. The Loss-of-Fluid Test Program ended in 1985. However, beginning in 1980, the area also was used to conduct work with material from the Three-Mile Island reactor accident (that work was completed in 2001).

Establishment of remedial actions was completed for TAN in 2007; decontamination and decommissioning of the remaining facilities without an operational mission was completed in 2008(INL 2015b).

The Radiological Response Training Range is located at TAN. It has a unique capability to provide a large outdoor testing and training location where short-lived, dispersed radioactive materials can be disseminated or radioactive sources placed to provide direct support to federal agencies responsible for the nuclear forensics mission(DOE 2010)).

A Stand-Off Experiment Range with the capability to perform outdoor accelerator testing has been established at TAN. The range is authorized to use linear particle accelerators (i.e., linacs) to perform research and development of active interrogation technologies for nuclear materials at standoff distances (INL 2015d, DOE 2011).

\subsubsection{Specific Manufacturing Capability}

The Specific Manufacturing Capability Project is also located at TAN. The Specific Manufacturing Capability is the facility complex responsible for production of heavy armor that helps make U.S. Army Abrams Tanks the world's best armored vehicles. The Specific Manufacturing Capability delivered its first product in October 1987, achieved full production capacity in 1988, and in 1998 delivered its $3,000^{\text {th }}$ unit. It manufactured protective armor for the U.S. Army's main battle tank- the M1A1 and M1A2. The manufacture of the Abrams M1A1 Main Battle Tank entailed converting depleted uranium billets into a finished armor package using molten salt baths, rolling and cleaning operations, and configuration of materials using standard machine shop equipment such as lathes, mills, punches, shears, and lasers (INL 2015a).

\subsubsection{Naval Reactors Facility}

NRF, which is located about 52 miles northwest of Idaho Falls in Butte County in central INL, was established in 1949 when the U.S. Atomic Commission, DOE's predecessor, created INL as the National 
Reactor Testing Station. Only about 84of the NRF site's 4,400 acres are developed. NRF was originally a part of Bettis Atomic Power Laboratory, operated by Westinghouse Electric Corporation under the supervision of DOE's Office of Naval Reactors. While NRF is not managed by the DOE's National Nuclear Security Administration, its work advances the National Nuclear Security Administration's mission.

NRF was created to support the U.S. Navy's Nuclear Propulsion Program. For 50years, NRF tested reactor designs, received naval spent nuclear fuel for examination and storage, and trained approximately 40,000 navy personnel using prototypes to operate nuclear power plants on ship. From the early 1950s through the mid-1990s, NRF built and operated prototype nuclear propulsion plants for submarines and aircraft carriers. While the complex consists of three naval nuclear reactor prototype plants, the Expended Core Facility, Dry Fuel Storage Facility, and support buildings, only the Expended Core Facility remains active.

The Expended Core Facility, which was built in 1958, receives, inspects, and conducts research on, and provides temporary storage for naval spent nuclear fuel. It also prepares and examines developmental nuclear fuel material samples. NRF work helps in the design of longer-lived cores, minimizing the creation of spent nuclear fuel and the need for disposition.

On June 4, 2008, an agreement between the State of Idaho and the U.S. Navy was announced. The agreement extends the Navy's nuclear operations at INL beyond 2035. As a result, the Naval Nuclear Propulsion Program plans to refurbish its INL facilities for long-term operations(Global Security 2011b).

\subsubsection{Integrated Waste Treatment Facility}

The Integrated Waste Treatment Unit is a newly constructed facility that is designed to treat900,000 gallons of radioactive liquid waste stored in underground tanks at a former Cold War spent nuclear fuel reprocessing facility located at DOE's Idaho Site.

The Integrated Waste Treatment Unit is a $53,000-\mathrm{ft}^{2}$ facility that will use a steam-reforming technology to heat upthe liquid waste, essentially drying it; consolidating the solid, granular material; packagingit in stainless steel canisters; and storing the containers in above-ground concrete vaults atthe site. Ultimately, the treated material will be transported to a national geologic repositoryfor permanent disposal.

Any facility emissions generated during the treatment campaign will be filtered through high-efficiency particulate air filters to "scrub" discharges to ensure compliancewith state and federal air quality requirements(DOE-ID 20015).

\subsubsection{Geology}

The INL resides in the eastern Snake River Plain, a low-relief volcanic province surrounded by mountainous regions. Features to the south and east of the site are similar to those found on the site, characterized by relatively flat topography punctuated by several prominent volcanic buttes and numerous basalt flows. The average surface elevation on the INL Site is approximately $1,500 \mathrm{~m}(5,000 \mathrm{ft})$ above sea level; however, isolated volcanic buttes reach elevations of nearly 2,000 m (6,600 ft). The Lost River and Lemhi Ranges and mouths of the valleys of the Big Lost and Little Lost Rivers bound the INL Site on the west and northwest. On the north, the mouth of the Birch Creek Valley and the southern tip of the Beaverhead Mountains of the Bitterroot Range bound the INL Site on the Idaho-Montana border. Peaks that are immediately north and west of the site borders approach 3,300 $\mathrm{m}(11,000 \mathrm{ft})$.

The predominant topographic features within the boundaries of the INL Site are the Twin Buttes (i.e., Middle and East Buttes). Big Southern Butte, located approximately $4 \mathrm{~km}$ (2.5 miles) south of the site boundary, is the tallest surface feature within the Snake River Plain, reaching an elevation of 2,300 m $(7,600 \mathrm{ft})$. These buttes provide the most conspicuous evidence of the volcanic origin of the Snake River 
Plain, although numerous smaller buttes, cinder cones, lava outcrops, and lava tubes may be found in the area.

Geologically, the Snake River Plain is thought to have been formed by the southwestward migration of the North American tectonic plate over a stationary hot spot in the earth's mantle, forming a linear volcanic province extending from Yellowstone National Park to southwestern Idaho (INL 2015b).

Explosive volcanic activity in the area between 4 and 10 million years ago formed silicic lava flows and pyroclastic deposits extending to depths of at least 3,000 $\mathrm{m}(10,000 \mathrm{ft})$ below the surface of INL (INL 2015b). These rhyolite rocks underlie the more recent basalt lava flows, which are interbedded with sediment, forming a highly permeable aquifer(INL 2015b). Basalt lava flows at the surface on INL range in age from $\sim 13,000$ to 1.2 million years (Kuntz et al 1994).

In addition to the locally generated basalt outcrops and flows, the principle surface materials at the INL Site include alluvium, lakebed or lacustrine sediment, slope wash sediment and talus, silicic volcanic rocks, and sedimentary rocks. These materials are deposited as sediment transported to the area by wind, water, or gravity.

\section{Seismology}

Compilations of historic earthquakes starting in 1850 combined with those instrumentally detected ending in 2014 show that the eastern Snake River Plain has much less earthquake activity than the surrounding mountainous regions (e.g., Peterson et al., 2014). The detailed seismic monitoring by the INL from 1972 to 2014 show that over 80 micro-earthquakes of magnitudes less than 2.5 have occurred in the eastern Snake River Plain. Of these, 17 events were located within the INL boundaries and 29 in the vicinity of the Craters of the Moon National Monument (Payne et al. 2014).

In contrast, thousands of earthquakes have occurred outside the eastern Snake River Plain and the spatial distribution of epicenters forms a parabolic shape that has its apex at Yellowstone (University of Utah 2015). The western limb of the parabola includes the epicenter of the 1983 moment magnitude 6.9 Borah Peak, Idaho earthquake. Although this earthquake was felt at INL, its epicenter was 53 to 67 miles from INL facilities and caused no significant damage.

The closest faults are located along the INL's western boundary. The Lost River, Lemhi, and Beaverhead normal faults bound the western sides of mountain ranges with the same names. Repeated earthquakes on these faults formed the mountains and their respective valleys over the last 16 million years. The 1983 earthquake ruptured the central section of the Lost River fault producing a 22 mile long fault scarp. Based on field studies, the most recent earthquakes occurred on the Lost River and Lemhi fault southern segments closest to INL sometime between 15,000 and 26,000 years ago (USGS 2015).

\subsubsection{Water}

The primary groundwater source of the region is the Eastern Snake River Plain Aquifer(Figure 3). The Eastern Snake River Plain Aquifers approximately $320 \mathrm{~km}$ (199 miles) long, 30 to $100 \mathrm{~km}$ (20 to 60 miles) wide, and encompasses an area of about 2,500,000 hectares $\left(9,650 \mathrm{mi}^{2}\right)$. This sole-source aquifer is one of the most productive in the United States, is a source of process and drinking water to more than 200,000 people, and supplies irrigation water to a large, regional agricultural and aquaculture economy.

The depth to the Eastern Snake River Plain Aquifer varies from approximately $60 \mathrm{~m}(200 \mathrm{ft})$ in the northern part of the INL Site to more than $270 \mathrm{~m}(900 \mathrm{ft})$ in the southern part. The aquifer is recharged from infiltrating precipitation and irrigation seepage, runoff from the surrounding highlands, and groundwater underflows from the surrounding watersheds. Groundwater in the Eastern Snake River Plain Aquifer generally flows southwest; however, locally the direction of flow is influenced by recharge from 
rivers, surface water, spreading areas, and heterogeneities in the aquifer. Groundwater flow rates in the vicinity of the INL Site range from approximately 1.5 to $6 \mathrm{~m}$ (5 to $20 \mathrm{ft}$ ) per day.

Annual rainfall at the INL Site is light, and the region is classified as arid to semiarid. The long-term average (from March 1950 through 2005) annual precipitation at the Site is $21.6 \mathrm{~cm}$ ( $8.5 \mathrm{in}$. at the CFA station). Monthly precipitation is usually highest in April, May, and June and lowest in July and October. The average daily temperature is $17.1^{\circ} \mathrm{C}\left(62.7^{\circ} \mathrm{F}\right)$ in the summer and the average daily minimum temperature is $-5.5^{\circ} \mathrm{C}\left(22.1^{\circ} \mathrm{F}\right)$ in the winter. The INL Site is in the belt of prevailing westerly winds, which are channeled within the plain to produce a west-southeasterly or southwesterly wind at most locations on the INL Site(INL 2015b).

\subsubsection{Climate}

The physiographic features of INL result in three distinct local-climatic zones (Figure 4).Northwest INL is influenced by down-canyon winds and up valley flows that originate in the southeast-to-northwest trending valleys that dominate the terrain northwest of INL. Northwest INL is also influenced by the rain-shadow effects of these mountains. Southwest INL is commonly influenced by shallow down-valley winds that are associated with the Big Lost River channel and by strong pre-frontal southwesterly winds and frequent afternoon winds, also from the southwest, that result from the diurnal heating cycle.

Southeast INL is isolated from the channeling flows that commonly affect the western portions of the site. In that area, temperatures, cloud cover, and surface winds are influenced by the subtle features of topography and higher elevation along the southern perimeter of INL (Clawson et al. 2007).

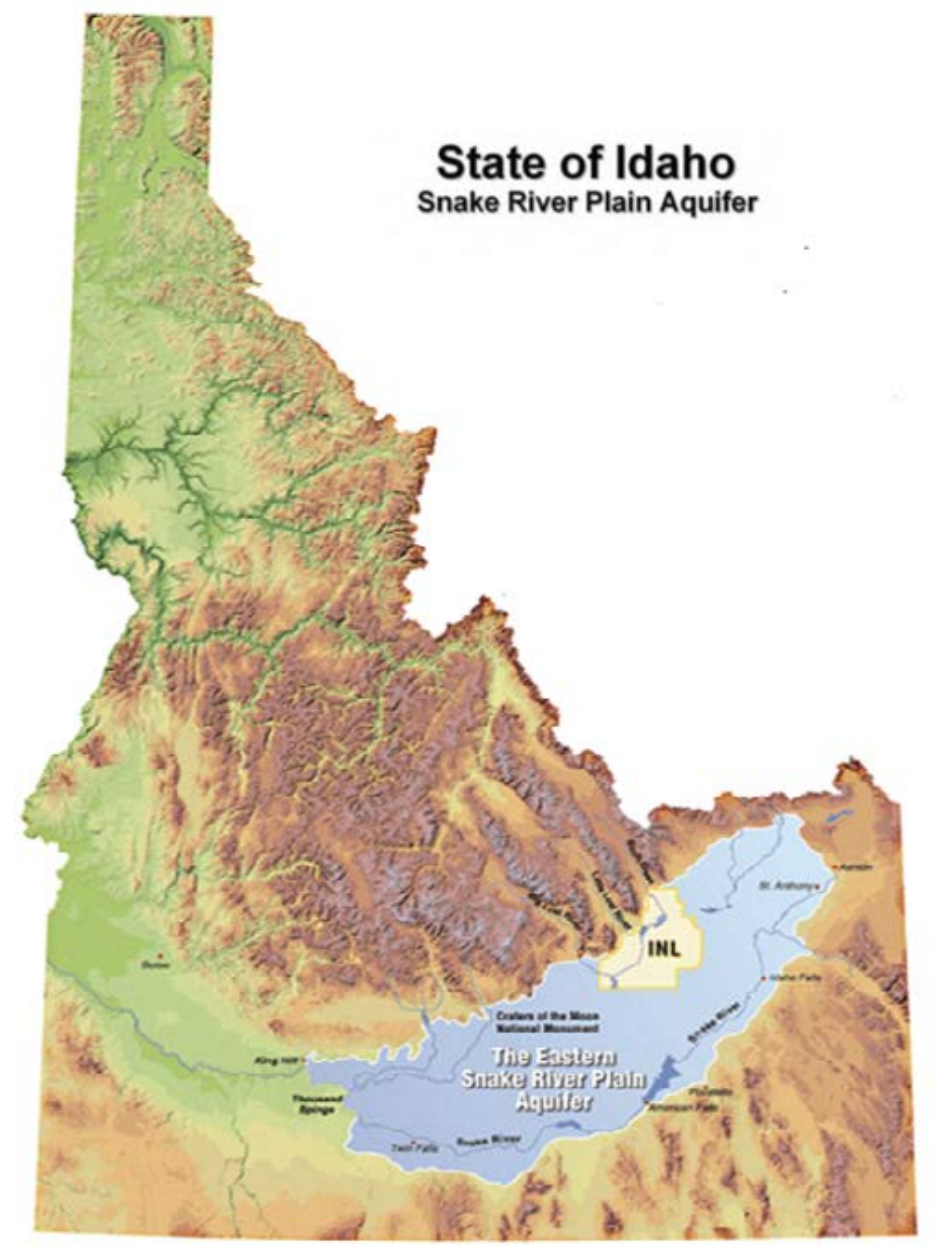

Figure 3. Eastern Snake River Plain Aquifer (Gellar 2006). 


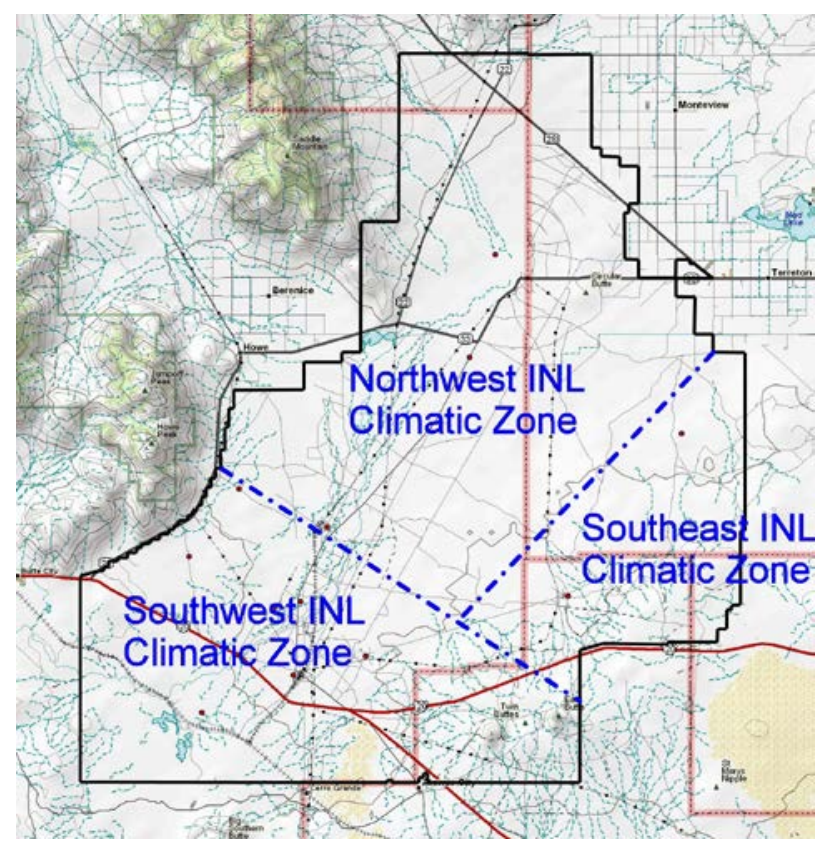

Figure 4. The three distinct INL local-climate zones(Clawson et al. 2007).

The means and extremes of daily temperatures at CFA from 1950 through 2006 are summarized in Table 1. The maximum air temperature recorded at CFA was $105^{\circ} \mathrm{F}$ while the minimum was $47^{\circ} \mathrm{F}$ (Clawson et al. 2007).

Table 1. Daily air temperature extremes summarized by month for CFA. ${ }^{a}$

\begin{tabular}{lcccc}
\hline & $\begin{array}{c}\text { Highest Daily } \\
\text { Maximum }\end{array}$ & $\begin{array}{c}\text { Lowest Daily } \\
\text { Minimum }\end{array}$ & $\begin{array}{c}\text { Highest Daily } \\
\text { Average }\end{array}$ & $\begin{array}{c}\text { Lowest Daily } \\
\text { Average }\end{array}$ \\
\hline January & 55 & -40 & 44 & -20 \\
February & 60 & -36 & 45 & -23 \\
March & 73 & -28 & 54 & -6 \\
April & 86 & 6 & 63 & 22 \\
May & 96 & 13 & 76 & 30 \\
June & 100 & 23 & 83 & 39 \\
July & 105 & 28 & 83 & 49 \\
August & 102 & 24 & 83 & 46 \\
September & 96 & 12 & 74 & 30 \\
October & 87 & -6 & 64 & -9 \\
November & 67 & -24 & 57 & -28 \\
December & 57 & -47 & 47 & -28 \\
Annual & 105 & -47 & 83 & \\
\hline
\end{tabular}

a. Note: Data period of record spans January 1950 through December 2006.

Daily precipitation values have been measured at CFA since March 1950 (Table 2).A pronounced precipitation peak occurs in May and June. The average for these two months is approximately $1.2 \mathrm{in}$. at CFA. The average annual precipitation at CFA is 8.51 in. The greatest monthly precipitation total measured at CFA was 4.64 in. during June 1995. There have been instances of no measurable precipitation recorded at CFA (traces excluded) for every month of the year except May.Long periods without precipitation are not uncommon at INL (Clawson et al. 2007). 
Table 2. Average total monthly and annual precipitation (water equivalent) for CFA. ${ }^{\text {a }}$

\begin{tabular}{lccc}
\hline & Average & $\begin{array}{c}\text { Highest } \\
\text { (inches) }\end{array}$ & Lowest \\
\hline January & 0.68 & 2.56 & $0.00^{\mathrm{b}}$ \\
February & 0.68 & 2.40 & 0.00 \\
March & 0.62 & 2.03 & 0.00 \\
April & 0.77 & 2.50 & 0.00 \\
May & 1.22 & 4.42 & 0.02 \\
June & 1.18 & 4.64 & 0.00 \\
July & 0.48 & 2.29 & 0.00 \\
August & 0.50 & 3.27 & 0.00 \\
September & 0.64 & 3.52 & 0.00 \\
October & 0.51 & 1.67 & 0.00 \\
November & 0.61 & 1.74 & 0.00 \\
December & 0.71 & 3.43 & 0.00 \\
Annual & 8.51 & 14.40 & 4.45 \\
\hline
\end{tabular}

a. Data period of record spans March 1950 through December 2006.

b. Trace amounts are not considered as precipitation.

Several other types of meteorological phenomena occur at INL, such as thunderstorms, lightning, hail, airborne dust and sand, dust devils, blowing snow, icing, and tornadoes.

\subsubsection{Thunderstorms}

A thunderstorm-day is defined by the National Weather Serviceas a day when thunder is heard at a given observing station. According to the definition, lightning does not have to be seen and rain fall and/or hail is not required. Following this strict definition, INL may experience an average of two or three thunderstorm days during each of the summer months from June through August, with considerable year-to-year variation. At INL, thunderstorms have been observed during every month of the year. However, they are seldom observed during the months of November through February.

Thunderstorms over INL are usually much less severe than what is normally experienced in the mountains surrounding the Eastern Snake River Plain or east of the Rocky Mountains. This is due, in part, to high cloud-base altitudes. Hence, the precipitation from many thunderstorms evaporates before reaching the ground. The frequent result is little or no measurable precipitation. Occasionally, however, rain amounts exceeding the long-term average may result from a single thunderstorm. Thunderstorms at INL may be accompanied by micro bursts (i.e., strong, localized, gusty winds). These micro bursts can produce dust storms and occasional wind damage. Thunderstorms may also be accompanied by cloud-toground and cloud-to-cloud lightning.

\subsubsection{Lightning}

INL is currently monitored by the U.S. Bureau of Land Management Interagency Fire Center lightning detection system. This system detects the location and number of lightning strikes in real time for wild fire control. The lack of natural targets and the poor conductivity of the dry desert soil and underlying lava rock cause man-made structures at INL to be susceptible to lightning strikes(Clawson et al. 2007).

\subsubsection{Hail}

Small hail has been observed to occasionally occur in conjunction with thunderstorms. Hail size is usually smaller than 1/4-in. in diameter, but may range up to 3/4-in. on very rare occasions. No hail damage has ever been reported at INL. Crop damage from hail on neighboring farms across the Eastern 
Snake River Plain is not unusual. Property damage in the City of Idaho Falls has been reported, as well as in other local cities. Damage from hail still remains a possibility at INL.

\subsubsection{Airborne Dust and Sand}

Blowing dust and drifting sand can be a nuisance when the winds are strong in certain areas of INL. These conditions may particularly affect the activities of construction personnel during the spring months after the winter thaw, when strong frontal systems pass through the Eastern Snake River Plain, and during the summer months, when thunderstorms are near.

\subsubsection{Dust Devils}

Dust devils are small atmospheric vortices that are generated over hot land surfaces. Dust devils are common in the summer at INL when intense solar heating of the ground makes dust devil formation possible. They usually occur on calm, sunny days. Dust devils pick up dust and pebbles and can overturn, blow down, or carry off unsecured objects. The dust cloud may be several hundred yards in diameter and extend several thousand feet into the air.

\subsubsection{Blowing Snow}

Blowing and/or drifting snow sometimes becomes a hazard and nuisance during the winter months at INL. Blowing snow greatly reduces visibility and slows down transportation. On rare occasions, visibility has been reduced to zero in extreme blizzard conditions. Blowing snow usually accumulates in drifts on the leeward side of buildings, vehicles, fence posts, and vegetation. Drifts may occasionally render parking lots and highways on the INL Site and access highways to INL impassable and cause traffic to be rerouted(Clawson et al. 2007).

\subsubsection{1 lcing}

Rime ice occurs when fog droplets impinge on objects at temperatures below freezing. The accumulation of rime ice on power lines and air intakes has not been a constraint to operations at INL. Severe glaze icing, which accompanies freezing rain, rarely occurs at INL. Glaze ice results in slippery sidewalks and roads and slows transportation. Glaze ice accumulation has been insufficient to damage power lines or communication cables at INL.

\subsubsection{Tornados}

The total number of tornadoes in Idaho reported to the Storm Prediction Center for the years 1950 through 2006 was 181. They occur most frequently during the month of June ( $25 \%$ of occurrences), but are also common in April, May, July, and August (14, 18, 14, and 13\% of occurrences, respectively).

Each tornado is classified using the Fujita Scale system that rates the degree of damage to the strength of the winds. The Fujita Scale ranges from F0 (i.e., little damage) to F5 (i.e., most intense damage).Sixty-one percent of all Idaho tornadoes reported during this period were F0 (i.e., "Gale Tornado," 40 to $72 \mathrm{mph}$, some damage to chimneys; breaks branches off trees; pushes over shallowrooted trees; and damages sign boards), 33\% were F1 (i.e., "Moderate Tornado," 73 to $112 \mathrm{mph}$, peels surface off roofs; mobile homes pushed off foundations or overturned; moving autos pushed off roads; and attached garages may be destroyed), and 6\% were F2 (i.e., "Significant Tornado," 113 to $157 \mathrm{mph}$, considerable damage, including roofs torn off frame houses; mobile homes demolished; boxcars pushed over; large trees snapped or uprooted; and light object missiles generated). To-date, Idaho has not experienced a "Severe Tornado" or tornado exceeding F2 in classification. This potentiality is low, given Idaho's mountain setting and characteristically dry (when compared to the U.S. Midwest) air masses. Six tornados have been reported across INL (Table 3). A supplemental record of funnel clouds and tornado sightings has been maintained by National Oceanic and Atmospheric Administration personal for INL(Clawson et al. 2007). 
Table 3. Funnel cloud and tornado sightings observed at INL. ${ }^{a}$

\begin{tabular}{|c|c|c|c|}
\hline Date & $\begin{array}{l}\text { Time } \\
(\mathrm{MST})\end{array}$ & Location & Type of Activity \\
\hline April 28, 1954 & 1220 & 6 miles northeast of Atomic City & F0 Tornado \\
\hline June 9, 1954 & 1210 & 5.5 miles northeast of Atomic City & F0 Tornado \\
\hline June 6,1967 & 1200 & 1 mile southeast of MFC & F0 Tornado ${ }^{\mathrm{d}}$ \\
\hline July 27, 1972 & 1330 & 3 miles north northeast of MFC & F1 Tornado ${ }^{\mathrm{d}}$ \\
\hline July 20, 1974 & 1253 & $\begin{array}{l}\text { Within a triangle formed by Howe, the } \\
\text { Advanced Test Reactor Complex, and NRF }\end{array}$ & 2 Funnel clouds ${ }^{c}$ \\
\hline May 8, 1975 & $\mathrm{M}^{\mathrm{b}}$ & Near Middle Butte & 2 Funnel clouds ${ }^{c}$ \\
\hline July 23, 1984 & 1225 & $\begin{array}{l}10 \text { miles west south-west of the Advanced Test } \\
\text { Reactor Complex }\end{array}$ & 1 Funnel cloud $^{\mathrm{c}}$ \\
\hline June 16, 1998 & 0915 & 3 miles east of DEA & F0 Tornado ${ }^{d}$ \\
\hline September 1,2000 & 1600 & 10 miles east of Arco & 1 Funnel cloud $^{\mathrm{c}}$ \\
\hline April 4, 2006 & 1905 & 5 miles southwest of Monteview & F0 Tornado ${ }^{\mathrm{d}}$ \\
\hline
\end{tabular}

\subsubsection{Range Fires}

From 1994 to 2006, over 200,000 acres at INL and several hundred thousand acres of public lands managed by the Bureau of Land Management burned on the Snake River Plain of southeast Idaho. Range fires have threatened INL facilities and have exposed soils to wind erosion, resulting in severe dust storms that have impacted operations and created traffic hazards that persisted for weeks.

Statewide, approximately $65 \%$ of Idaho range fires are lightning-caused. At INL, range fires typically occur in the late summer and fall, when annual grasses are dry, lightning activity is high, and dry atmospheric conditions evaporate much of the storm's rain before it reaches the ground. Lightning-caused fires spread rapidly when fanned by high winds that frequently accompany thunderstorms. However, the wind vector persistence of thunderstorm winds is limited.

Human-caused wildfires have been most damaging when started during conditions of persistent, strong, southwesterly winds that are a common occurrence at INL, when strong solar heating links the surface winds with strong southwesterly synoptic winds aloft (Clawson et al. 2007).

\subsubsection{Biota}

The natural vegetation at the INL Site primarily consists of a shrub over story with an understory of perennial grasses and forbs. Most vegetation communities within the site boundaries are dominated by various species or subspecies of sagebrush; some communities that are dominated by saltbush, juniper, crested wheatgrass, and Indian rice grass are present and distributed throughout the INL Site. The INL Site supports over 420 species of flowering plants(INL 2015b).

\subsection{Sagebrush-Steppe Ecosystem Reserve}

The INL Site lies within the largest sagebrush-steppe region within North America. Sagebrush-steppe is a type of dry habitat characterized by sagebrush and other shrubs and short grasses. The National Biological Service identified the sagebrush-steppe ecosystem as critically endangered across its entire range in 1995. On July 17,1999, the Secretary of Energy and representatives of the U.S. Fish and Wildlife Service, the Bureau of Land Management, and the Idaho Department of Fish and Game designated a portion of the INL Site as the Sagebrush-Steppe Ecosystem Reserve. The Sagebrush-Steppe Ecosystem Reserve, which covers approximately $300 \mathrm{~km}^{2}\left(115 \mathrm{mi}^{2}\right)$ in the northwest corner of the INL Site, was 
designated to ensure this portion of the ecosystem receives special consideration. Figure 5 shows the location of the Sagebrush-Steppe Ecosystem Reserve at the INL Site. Because of the inherent ecological benefits of such a large tract of protected and relatively undisturbed habitat, the scientific community recognizes this acreage as providing an excellent opportunity for research.

The Bureau of Land Management and DOE have prepared a management plan for the INL Sagebrush-Steppe Ecosystem Reserve with input from the Idaho Department of Fish and Game, U.S. Fish and Wildlife Service, and Native American Tribes. The Sagebrush-Steppe Ecosystem Reserve is managed as a laboratory where all native ecosystem components, cultural resources, and Native American tribal values are conserved, yet opportunities for scientific investigation of the resources present on the INL Site are provided. The Sagebrush-Steppe Ecosystem Reserve Final Management Plan (ESER 2004) discusses wildfire suppression, livestock grazing, road management, weed control, and protection of cultural resources. The management plan identified four management goals that are used as a framework for facilitating long-term health of this unique ecosystem. The first goal identified in the management plan was addressed with the release of a Sensitive Animal Species Inventory in November 2007 on the INL Sagebrush Steppe Ecosystem Reserve, which establishes "a baseline of resource data to identify and prioritize immediate needs for management adjustment."

\subsubsection{Fauna}

Estimates of the total number of species of vertebrate fauna found on the INL Site vary. Perhaps the most reliable information on vertebrate fauna on the INL Site is provided by the INL Environmental Surveillance, Education, and Research Program(INL 2015b), which describes some 211 vertebrate species (i.e., five fish, one amphibian, nine reptile, 37 mammal, and 159 bird species) as having been documented on the INL Site. Of these species, 56 are considered to be year-round residents, whereas the rest are partial-year residents that were observed during specific seasons or during migration. Most of the migratory species are birds. An additional nine fish, five amphibian, five reptile, 13 bird, and 14 mammal species are considered as possibly occurring at the site, because portions of their range overlap the INL Site area or they have been reported within $30 \mathrm{~km}$ (18 miles) of the INL Site. However, no verified observations of these species have been reported on the INL Site. 


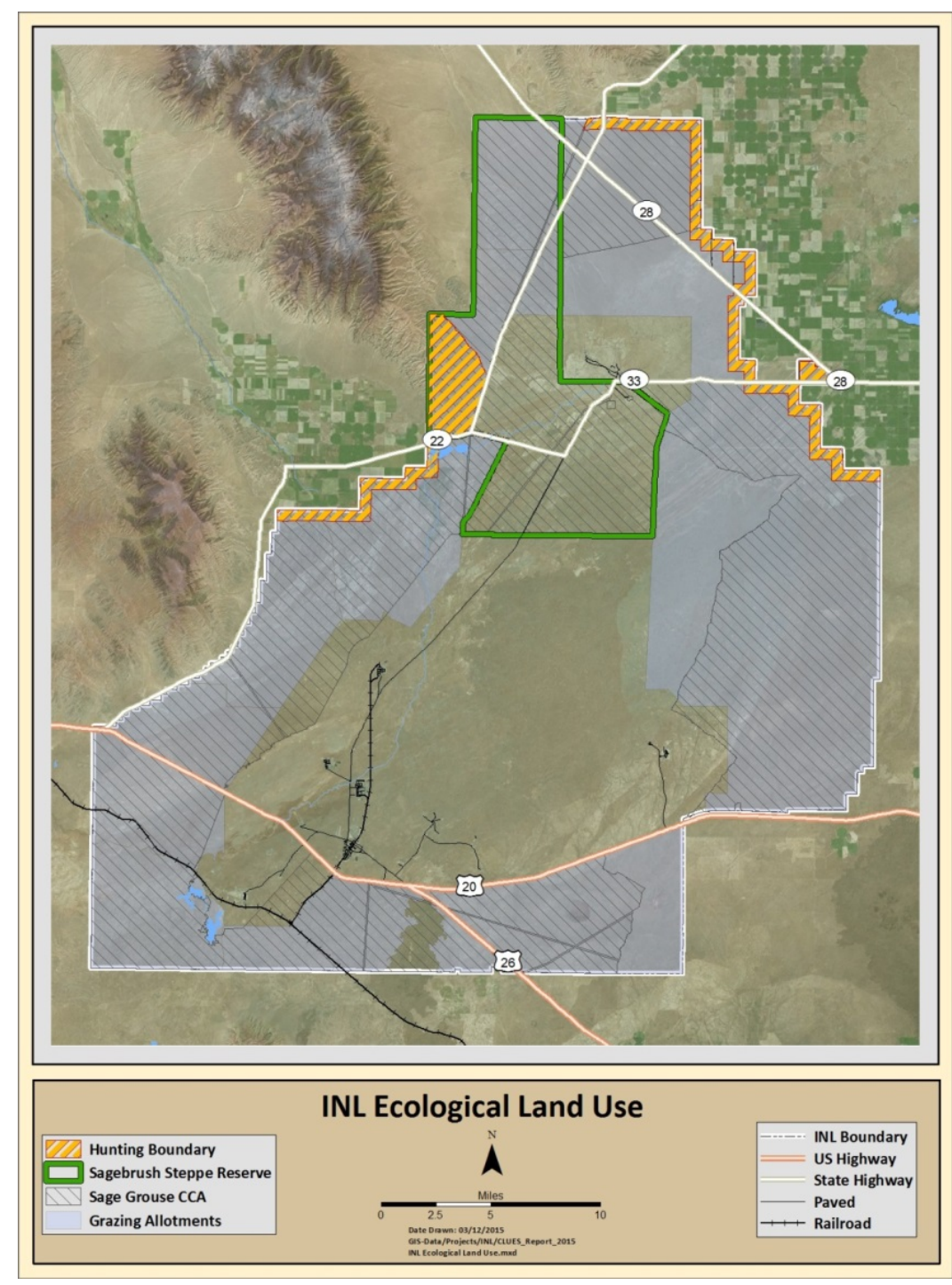

Figure 5. INL ecological land use (INL 2015b).

Fish species reported on the INL Site are limited to the Big Lost River during years when water flow is sufficient. However, periods of drought and upstream water diversion for agricultural and flood-prevention purposes has severely restricted the flow of the Big Lost River on the INL Site, thereby restricting the presence of native fish species. Similarly, the Great Basin spadefoot toad, the INL Site's only reported resident amphibian, is limited by water flow in the Big Lost River. Reptiles include five species of snake, three species of lizards, and the western skink.

Birds represent the largest group of vertebrates found on the INL Site, although, as pointed out above, many bird species are seasonal residents. Raptors, songbirds, and waterfowl are all well represented and comprise important ecological components of the sagebrush-steppe community. The INL Site is inhabited by 14 species of sparrows and allies, six species of swallows, 20 species of ducks and geese, and 24 species of raptors. Among these species is the bald eagle, which is seen on or near the INL Site during winter. Sage-grouse is another species of importance that is present on the INL Site.

In 2014, DOE-ID voluntarily entered into a Candidate Conservation Agreement with the U.S. Fish and Wildlife Service to protect greater sage-grouse and its habitats on the INL Site, while allowing DOE flexibility in conducting its current and future missions. This was the first such agreement signed in Idaho 
for sage-grouse. The Candidate Conservation Agreement complements Idaho's State Alternative, developed in 2012 by Governor C. L. "Butch" Otter's task force, and other efforts to preclude the need for sage-grouse to be listed under the Endangered Species Act. The INL Site conservation framework protects lands within a 1-km (0.6-mile) radius of all known active leks (i.e., traditional breeding grounds) on the INL Site and establishes a sage-grouse conservation area that limits infrastructure development and human disturbance in approximately $68 \%$ of remaining sagebrush-dominated communities. Leks protected by the sage-grouse conservation area support an estimated $74 \%$ of the sage-grouse that breed on the INL Site. In addition to establishing a conservation framework, the Candidate Conservation Agreement identifies primary threats to sage-grouse and its habitats on the INL Site and introduces a set of new conservation measures that DOE commits to implement to minimize those threats. Successful implementation will promote preservation of sagebrush habitat, reduce or eliminate threats to sage-grouse, and increase understanding of habitat and population trends through long-term research and monitoring.

Although most of the 37 mammal species reported on the INL Site are small mammals, several important large mammals (such as mule deer) are present. Approximately 30\% of Idaho's pronghorn populations use the INL Site and surrounding areas for winter range. In addition, a small population of elk resides on the INL Site. Some small mammal species (such as the black-tailed jackrabbit) exhibit large population fluctuations and influence the abundance, reproduction, and migration of predators such as the coyote, bobcat, and raptors. Other observed predators include mountain lions and badgers.

\subsubsection{Special Status Wildlife}

The U.S. Fish and Wildlife Service provides a list, by county, of threatened and endangered species and other species of concern for the State of Idaho. The most recent U.S. Fish and Wildlife Service list (May 9, 2011) includes two threatened and endangered species and three candidate species that may occur within the five counties that encompass the INL Site. The Canada lynx and the grizzly bear are threatened species. Neither are expected to be present on the INL Site. The gray wolf was delisted on May 5, 2011, and is no longer afforded protection under the Endangered Species Act in Idaho; wolf populations in Idaho are managed by the state. Greater sage-grouse, yellow-billed cuckoo, and the wolverine are candidate species. Sage-grouse are generally considered obligates of the sagebrush-steppe system, requiring sagebrush for nesting, winter feeding, and shelter from weather and predators throughout the year. Sage-grouse are abundant at the INL Site. The yellow-billed cuckoo is a riparian-obligate species and is primarily associated with willow-cottonwood riparian forest.

Several other animal species were designated as sensitive that may be present on the INL Site. The bald eagle was delisted in 2007, but is still protected under the Bald and Golden Eagle Protection Act. This species often winters in the Little Lost River Valley just north of the INL Site and several have been known to winter on the INL Site. The American peregrine falcon (delisted, but being monitored) has been observed infrequently on the northern portion of the INL Site.

Among the mammal species recognized by other agencies that might be found on the INL Site are Merriam's shrew, pygmy rabbit, bobcat, Townsend's big-eared bat, long-eared myotis bats, and smallfooted myotis bats. Bird species of concern include ferruginous hawk, long-billed curlew, northern goshawk, ferruginous hawk, osprey, gyrfalcon, merlin, white-faced ibis, long-billed curlew, burrowing owl, prairie falcon, and loggerhead shrike. The northern sagebrush lizard is the single reptile on the U.S. Fish and Wildlife Service's list. 


\subsection{Infrastructure}

\subsubsection{Roadways}

Commercial transportation systems at the INL Site include road and highway systems, railroad systems, and airports. Approximately $6 \%$ of INL Site land (i.e., approximately 13,736 hectares $[34,000$ acres] $]$ is devoted to public roads and utility rights-of-way crossing the INL Site.

U.S. Highways 20 and 26 cross the southern portion of the INL Site, while Idaho State Highways 22, 28 , and 33 cross the northern portion (Figure 6 ). These paved public highways measure approximately $145 \mathrm{~km}$ (90 miles). The INL Site has an additional $140 \mathrm{~km}$ (87 miles) of non-public paved roads within its boundaries, approximately $29 \mathrm{~km}$ (18 miles) of which are considered service roads. Finally, an additional $161 \mathrm{~km}$ (100 miles) of unpaved roads and trails provide additional access for emergency, security, and service vehicles. Road use is restricted to employees and visitors on official business.

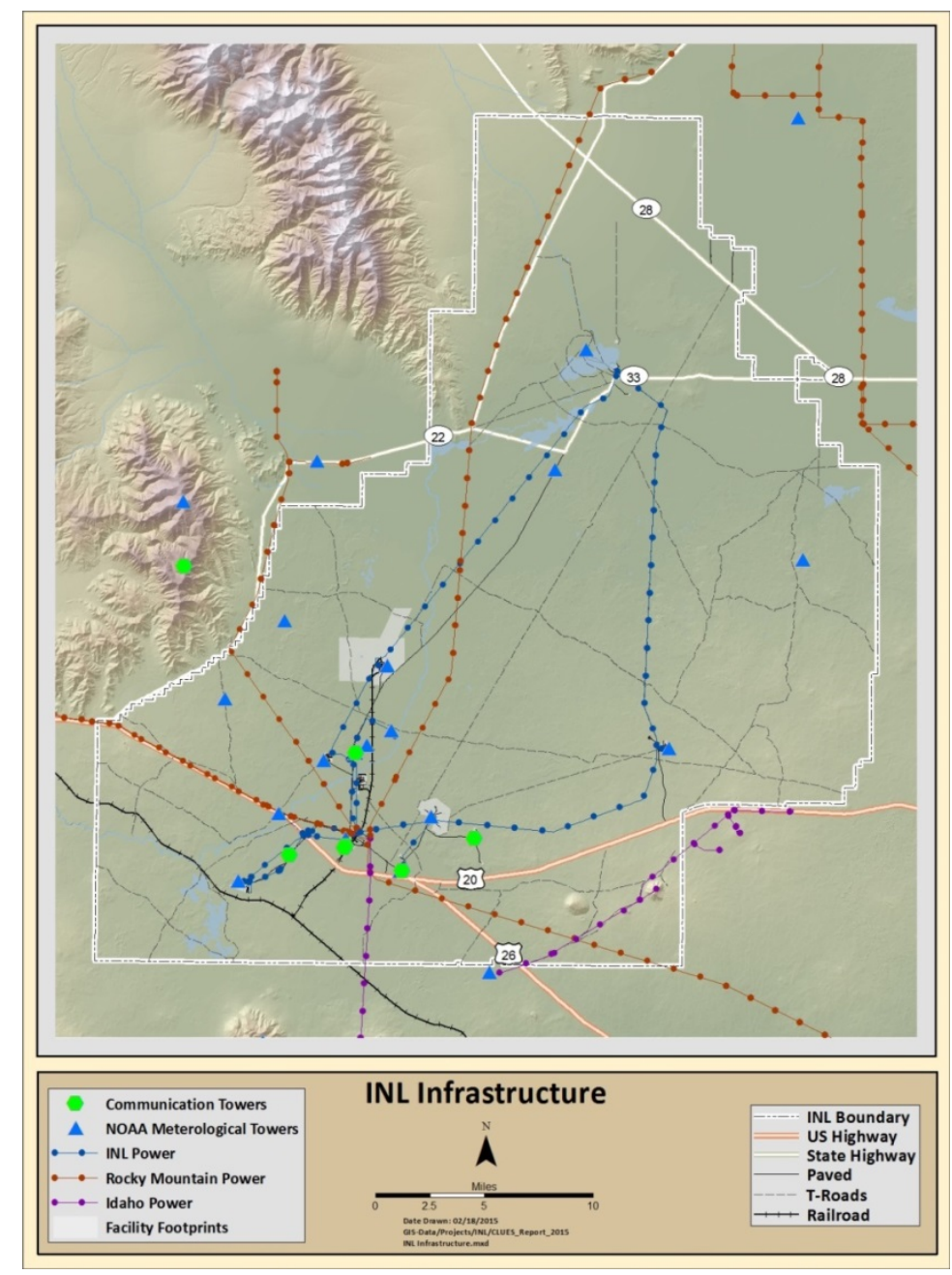

Figure 6. Idaho National Laboratory infrastructure.

In 2010, DOE approved a project to create an additional route within INL Site boundaries to transport shipments of materials and waste expected over the next 10 years between MFC and other INL Site facilities. The 21-km (13-mile) road is being constructed; it will be a nonpublic road encompassed entirely within the INL Site. 


\subsubsection{Railways}

The INL Site has several railways that cross its property (Figure 6). The Union Pacific Railroad's Mackay Branch Line services the southern portion of the INL Site through the Scoville Spur. The $23 \mathrm{~km}$ (14 miles) of the Mackay Branch Line, which terminates in the southern part of the INL Site, services the Union Pacific Railroad's main lines, which run from Butte, Montana, (on the north) to Pocatello, Idaho, and Salt Lake City, Utah (on the south). Interconnections are made from these locations throughout the United States.

A DOE-owned railroad track also passes north at Scoville Siding from Mackay Branch through CFA past the east side of INTEC and terminates within NRF. A spur line runs west to connect this track through the south end of the INTEC Fuel Storage Facility and to the coal-fired plant. A portion of this line is presently out of service.

\subsubsection{Airways}

The cities of Idaho Falls and Pocatello both have airports that provide passenger and cargo service in the vicinity of the INL Site. The Federal Aviation Administration requests that pilots avoid flights below $1,800 \mathrm{~m}(6,000 \mathrm{ft})$ above mean sea level when crossing the INL Site. The INL Site operates a $305 \times 30-\mathrm{m}$ $(1,000 \times 100-\mathrm{ft})$ airfield for testing of unmanned aerial vehicles.

\subsubsection{Utilities}

Commercial electric power is delivered to the operating areas ofthe INL Site by an extensive power transmission and distribution system (Figure 6). Offsite power is fed into the INL Site power transmission system through the Scoville substation. Power to the Scoville substation and INL Site is provided via two transmission lines from Rocky Mountain Power's Antelope substation.

The INL Site power system includes a 138-kV transmission loop that is $100 \mathrm{~km}$ (62 miles) long and feeds high-voltage substations. A separate $10-\mathrm{km}(6.2-\mathrm{mile}), 138-\mathrm{kV}$ line feeds the RWMC area with capacity in excess of $20 \mathrm{MW}$. The distribution system ranges in voltage from 13.8 to $2.4 \mathrm{kV}$ and is composed of approximately $97 \mathrm{~km}$ (60 miles) of overhead lines and several miles of underground lines. The transmission loop capacity is $50 \mathrm{MW}$. There are no gas or oil lines on the INL Site, although individual facilities may have propane or fuel storage tanks.

\subsubsection{Permitting}

The Idaho Department of Environmental Quality issues permits to regulate emissions of air pollutants, reuse of recycled water, and treatment, storage, and disposal of hazardous waste. The purpose of environmental permits is to protect public health and the environment. Permits establish the conditions under which facilities that generate pollution may operate. Permits represent a contract between the businesses and the government that the facilities will comply with applicable state and federal pollution control laws(IDEQ 2015).

\section{REFERENCES}

BSU, 2010, "INL Impacts an analysis of the effects of Idaho National Laboratory site operations on Idaho's economy," http://cobe.boisestate.edu/files/2010/12/Impacts_Brochure-Web1.pdf, 2010.

Census Bureau, 2011, State and County Quick Facts. http://quickfacts.census.gov/qfd/index.html, 2011.

Clawson, K. L., R. M. Eckman, N. F. Hukari, J. D. Rich, and N. R. Ricks, 2007, "Climatography of the Idaho National Laboratory 3rd Edition," NOAA Technical Memorandum OAR ARL-259, http://niwc.noaa.inel.gov/climate/INL_Climate 3rdEdition.pdf. 
DOE, 2010, “Idaho National Laboratory Radiological Response Training Range Environmental Assessment," DOE/EA-1776, October 2010, http://energy.gov/sites/prod/files/nepapub/nepa_documents/RedDont/EA-1776-FEA-2010.pdf.

DOE, 2011, "Idaho National Laboratory Stand-Off Experiment (SOX) Range Environmental Assessment," DOE/EA-1822, March 2011, http://www.id.energy.gov/insideNEID/PDF/SOX\%20Range\%20Final\%20EA\%20(March\%202011).p df.

DOE, 2014, "Draft Environmental Assessment on the Disposition of Five Signature Properties at Idaho National Laboratory,” DOE?EA-1984, May 2014, http://www.id.energy.gov/News/FInal\%20Draft\%20EA\%20Signature\%20Properties.pdf.

DOE-ID, 2004, "Hazardous Waste Management Act/Resource Conservation and Recovery Act Closure Plan for the Test Area North/Technical Support Facility Intermediate-Level Radioactive Waste Management System," DOE/ID-11053, Revision 3, July 2004,https://ar.icp.doe.gov/images/pdf/200508/2005082600859KAH.pdf.

DOE-ID, 2006, “What About a Major Earthquake?” http://www.id.doe.gov/news/PDF/06-GA5055301b.pdf.

DOE-ID, 2010,"Brief History of the Idaho National Laboratory (INL),"http://www.id.doe.gov/insideNEID/BriefHistory.htm.

DOE-ID, 2015, "Integrated Waste Treatment Facility Designed to Treat Liquid Radioactive Waste at DOE's Idaho Site," http://energy.gov/sites/prod/files/IWTU\%20at\%20Idaho\%20Fact\%20Sheet.pdf.

DOE Order 430.1B, "Real Property Asset Management,” U.S. Department of Energy.

Energy.gov, 2015, "Nuclear Facility Operations," http://energy.gov/ne/nuclear-reactortechnologies/nuclear-facility-operations.

EPA, 2009, "Idaho National Laboratory (USDOE) EPA ID\# ID4890008952," http://yosemite.epa.gov/r10/nplpad.nsf/0/cb601d3cf3b34eb6852565950047dc53!OpenDocument.

ESER, 2004, Sagebrush-Steppe Ecosystem Reserve Final Management Plan.

Gellar, D. 2006, “Eastern Snake River Plain Aquifer, Idaho,” Emporia State University GO 571, http://academic.emporia.edu/schulmem/hydro/TERM\%20PROJECTS/Geller/Eastern\%20Snake\%20R iver\%20Plain\%20Aquifer.html.

Global Security, 2011a, "Idaho National Laboratory: Radioactive Waste Management Complex,"http://www.globalsecurity.org/wmd/facility/idaho_inel-facility-rwmc.htm.

Global Security, 2011b, "Idaho National Laboratory: Naval Reactors Facility,"http://www.globalsecurity.org/wmd/facility/idaho_inel-facility-nrf.htm.

IDEQ, 2015, “Current Permits Issued by DEQ,"https://www.deq.idaho.gov/permitting/issued-permits/.

INL, 2015a, "INL Facilities,” http://www4vip.inl.gov/research/facilities/.

INL, 2015b, "Idaho National Laboratory Comprehensive Land Use and Environmental Stewardship Report," INL/EXT-05-00726, Revision 2, June 2015.

INL, 2015c, "Explosives Test Range,” http://www4vip.inl.gov/research/explosives-test-range/.

INL, 2015d, "Idaho Test Range," http://www4vip.inl.gov/research/idaho-test-range/.

Kuntz, M.A., Skipp, B., Lanphere, M.A., Scott, W.E., Pierce, K.L., Dalrymple, G.B., Champion, D.E., Embree, G.F., Page, W.R., Morgan, L.A., Smith, R.P., Hackett, W.R., and Rodgers, D.W., 1994, 
Geologic map of the Idaho National Engineering Laboratory and adjoining areas, eastern Idaho, U.S. Geological Survey Miscellaneous Investigation Map, I-2330, 1:100,000 scale.

Payne, S. J., D. F. Bruhn, J. M. Hodges, and R. G. Berg, 2014, "INL Seismic Monitoring Annual Report: January 1, 2012 - December 31, 2012,” INL/EXT-14-33937, December 2014,

Petersen, M.D., Frankel, A.D., Harmsen, S.C., Mueller, C.S., Haller, K.M., Wheeler, R.L., Wesson, R.L., Zeng, Y., Boyd, O.S., Perkins, D.M., Luco, N., Field, E.H., Wills, C.J., and Rukstales, K.S., 2008, "Documentation for the 2008 Update of the United States National Seismic Hazard Maps," U.S. Geological Survey Open-File Report 2008-1128.

University of Utah, 2015, "Yellowstone Hotspot Overview", http://www.yellowstonegis.utah.edu/research/hotspot.html.

USGS, 2015, "Quaternary Fold and Fault Database of the United States”, U.S. Geological Survey, http://earthquake.usgs.gov/hazards/qfaults/. 